\title{
Correction to: India-Africa Partnerships for Food Security and Capacity Building
}

\author{
Renu Modi and Meera Venkatachalam
}

\section{Correction to:}

R. Modi and M. Venkatachalam (eds.), India-Africa Partnerships for Food Security and Capacity Building, International Political Economy Series, https://doi.org/10.1007/978-3-030-54112-5

The original version of the book has been updated with the following belated corrections: The affiliation and the biography of the author Karin Costa Vazquez have been amended in FM and Chapter 15. The book has been updated with the changes.

The updated version of the book can be found at https://doi.org/10.1007/ 978-3-030-54112-5

(C) The Author(s) 2021

$\mathrm{Cl}$

R. Modi and M. Venkatachalam (eds.), India-Africa Partnerships

for Food Security and Capacity Building,

International Political Economy Series,

https://doi.org/10.1007/978-3-030-54112-5_18 